TABLE 4

\begin{tabular}{|c|c|c|}
\hline $\begin{array}{c}\text { Number of preda- } \\
\text { tors (out of 5 con- } \\
\text { sidered) }\end{array}$ & $\begin{array}{c}\text { Observed number of } \\
\text { bacterial strains } \\
\text { attacked by the fore- } \\
\text { going numbers of } \\
\text { predators }\end{array}$ & $\begin{array}{c}\text { Calculated number of } \\
\text { bacterial strains }\end{array}$ \\
\hline 0 & 7 & $6 \cdot 7$ \\
1 & 13 & $12 \cdot 1$ \\
2 & 13 & $16 \cdot 1$ \\
3 & 25 & $18 \cdot 5$ \\
4 & 12 & $15 \cdot 6$ \\
\hline 5 & 87 & $87 \cdot 0$ \\
\hline Total & 17 & \\
\hline
\end{tabular}

edible to predators than others, but that otherwise it is a matter of chance whether any one strain is edible to any one predator, and there is no tendency for predators to feed complementarily (that is, one generally preferring strains left uneaten by another). The actual mathematical distribution assumed, a type of modified binomial distribution, will shortly be described elsewhere by one of us (F. J. A.). It will be seen that the calculated numbers agree well with the observed.

Thus of the eight micro-predators tested together, five behave in the way just described, showing some tendency, but not a very pronounced one, to feed on the same selection of host bacteria; whereas the remaining three predators are each highly correlated. with one of the five already considered, and so not likely to affect appreciably the total number of bacterial strains edible to one or more of the predators. It is interesting to consider, as a matter of speculation, what percentage of the bacterial strains tested would remain inedible by any predator if more predators could be found having the same degree of independence from the five here considered and from one another as these five have from one another. We should expect the percentage of uneaten strains to vary with the total number of predators as shown in Table 5 .

TABLI 5

$\begin{array}{cc}\text { Number of different predators } & \% \text { of strains uneaten } \\ 5 & 7 \cdot 7 \\ 6 & 5 \cdot 9 \\ 10 & 2 \cdot 6 \\ 15 & 1 \cdot 3 \\ 20 & 0 \cdot 8\end{array}$

In Table 2 is also shown the relation of the five micro-predators to the Gram-staining of the bacterial strains. Two of the predators, Dictyostelium giganteum and Myxococcus fulvus, show a definite negative association, suggesting that they prefer bacterial strains that are Gram-negative. The same will also apply to the similarly behaved Dictyostelium mucoroides and Chondrococcus exiguus. It should be remembered that many soil organisms such as antibiotic actinomyces and fungi show a strong preference for Gram-positive bacteria. Such organisms will thus tend to be complementary to the above predators in their food preferences.

The remaining predators tested do not show any such association with the Gram-reaction.

\footnotetext{
' Singh, B. N., Ann. Appl. Biol., 28, 52 (1941).

'Singh, B. N., Ann. Appl. Biol., 29, 18 (1942).

'Singh, B. N., Brit. J. Exp. Path., 26, 316 (1945).

- Singh, B. N., Ann. Appl. Biol., 33, 112 (1946).

'Singh, B. N., Nature, 157, 133 (1946).

- Singh, B. N., J. Gen. Microbiol., 1, 1 (1947).

'Singh, B. N., J. Gen. Microbiol., 1, 11 (1947).

- Singh, B. N., J. Gen. Microbiol., in the press.

- Singh, B. N., J. Gen. Microbiol., in the press.

${ }^{10}$ Oxford, A. E., and Singh, B. N., Nature, 158, 745 (1946).
}

\section{RESEARCH AND DEVELOPMENT IN BRITISH COLONIAL TERRITORIES}

\section{Colonial Research Committee}

$\mathrm{T}$ HE fourth annual report of the Colonial Research Committee, published under the title "Colonial Research 1946-47"*, together with the fourth annual report of the Colonial Products Research Council, the third annual report of the Colonial Social Science Research Council and the second annual reports of the Colonial Medical Research Committee and of the Committee for Colonial Agricultural, Animal Health and Forestry Research, covers the period April 1, 1946-March 31, 1947, and refers again to the lightening of the task of the Committee by the creation of separate bodies to advise the Secretary of State on special aspects of reseach. Early in 1947, the Colonial Insecticides Committee was created, with Sir Ian Heilbron as chairman, to initiate research, including experimental field work, to examine schemes for research and experiment submitted by Colonial Governments or other appropriate bodies, to advise on problems concerning the use of insecticides, and to make available the latest scientific information to those concerned with the use of insecticides in the Colonies. This Committee has already decided to concern itself primarily with the experimental application of the results of fundamental insecticide research, but will also encourage and reinforce research projects of Colonial Government Departments as well as co-ordinate agricultural, medical and veterinary interests in the use of insecticides. Economic research has now been entrusted to a Colonial Economic Research Committee, with Sir Arnold Plant as chairman, which, working in close association with the Colonial Social Science Research Council, will advise the Secretary of State on economic research and statistics.

While the Colonial Research Committee continues to act as the central advisory body on expenditure schemes initiated by the other bodies, with the exception of the Colonial Products Research Council, its own report becomes essentially a cover note appended to the list of schemes approved for research grants, although the whole report is a most useful reference paper in view of the information it contains concerning membership of the various committees, etc. Referring to Dr. E. B. Worthington's appointment as joint secretary to the Committee, the report states that Dr. Worthington's services have been placed at the disposal of the East African Governor's Conference for a period of two years, to advise on the regional organisation of research in the three East African territories in which the Governor's Conference is interested. The Central African Council, established in 1945 as a consultative body to foster co-operation between Southern Rhodesia, Northern Rhodesia and Nyasaland, also decided to appoint a research secretary to survey existing facilities for research and report upon additional facilities required; but no definite steps were taken to consider the regional organisation of research in West Africa. Five Colonial Research fellowships were awarded during the year, but one was ultimately declined by the applicant.

- Colonial Offce. Colonial Research 1946-47. Pp. ii+72. (Cmd. 7151.) (London: H.M. Stationery Office, 1947.) 18. 3d. net. 
Dealing with specific fields of research, censuses were taken during the year in Aden, Ceylon, Cyprus, the Falkland Islands, Fiji and Western Pacific and St. Helena, and the urgent need for complete censuses in all Colonial territories in Africa is stressed. Regional fisheries research institutes are being organised in East, Central and West Africa, and funds are being made available from the Colonial Development and Welfare Research allocation for a Freshwater Research Station at Jinga in Uganda. The shortage of trained staff and equipment, however, are great obstacles to the development of fisheries. Recruitment of trained men has also been a difficulty at the headquarters of the Geodetic and Topographical Survey opened at Bushey Park in March 1946. Only about a quarter of the programme of air photography for West Africa was complete owing to bad photographic weather, but a large programme of air photography covering parts of all the East and Central African Colonies and the High Commissioners' Territories was arranged to start in May 1947. Dr. F. Dixey, appointed as geological adviser and director of Colonial geological surveys from January 1, 1947, has been studying the needs of such surveys in regard to organisation and expansion of staff, but expansion is likely to be hindered by the shortage of geologists. Active control campaigns against the desert locust in the Middle East and the East African and adjacent territories continued during the year, and considerable success was achieved, particularly with 'Gammexane' as poison in baits; a much more toxic spray for locusts from aircraft has been developed. The anticipated progress has not been made in the organisation of a meteorological service. Sixty-seven schemes approved for research grants during the year aggregated $£ 1,085,259$; eighteen were for agriculture, veterinary science, forestry or fisheries, twenty-seven for medical and thirteen for social sciences. Actual issues in respect of schemes during the year totalled $£ 164,329$.

\section{Colonial Products Research Council}

The report of the Colonial Products Research Council refers particularly to the work in Sir Norman Haworth's laboratory at the University of Birmingham on sugar and starch. The study of the chemistry of cane sugar and its immediate transformation products has resulted in the preparation of a sulphonamide derivative which is a promising chemothera. peutic agent, while derivatives of lævulinic acid with marked analgesic properties have been found. Sodium lævulinate appears to be superior in some respects to ethylene glycol as an anti-freeze agent, and the palmityl and stearyl derivatives of dianhydromannitol and dianhydrosorbitol may find application as detergents and emulsifiers. The chief feature of the work on starch is the separation of starch into amylopectin and amylose, and it appears that by first separating starch into these two components its industrial utilization could be greatly extended, amylopectin, for example, being superior to starch as a beater size in paper-making, while amylose acetate is compatible with cellulose acetate in the manufacture of textile fibres and films. It has also been observed that starch glycollate is an ideal indicator in iodometry analysis.

As a result of the work on arrowroot, a process has now been devised which allows the extraction by a grinding mill of special design of practically the whole of the starch from the roots. In the field of citrus products, work at the Imperial College of
Science and Technology, London, under Sir Ian Heilbron and Dr. E. R. H. Jones has led to the determination of the nature of the troublesome deposit formed in Tanganyika bitter orange oil during shipment and storage, while work under Prof. T. P. Hilditch at the University of Liverpool suggests that the oil prepared from specially heat-treated seeds of a West African vine (Tetracarpidium conophorum) may prove a satisfactory substitute for linseed oil. Other work has been concerned with plants of possible medicinal and insecticidal value, including the exhaustive fractionation of the extract from the flowers of Brayera anthelmintica and the separation of the principal carbohydrate fractions of the tissues of Hydrocotyle asiastica. Ereotion of the laboratory of the Colonial Microbiological Research Institute at Trinidad commenced in February 1947, and before leaving for Trinidad, Dr. A. C. Thaysen continued his study of the Actinomyces, developing a new culture medium. Dr. Thaysen is to study the fermentation processes which occur after the harvesting of cocoa beans and on which the flavour of the cocoa is believed largely to depend.

In September 1946, Sir Ian Heilbron and the Director of Research (Dr. J. L. Simonsen) visited Kenya, Tanganyika, Uganda and Zanzibar, discussing the position of both the Industrial Management Board and the East African Industrial Research Board with the managing director and acting-chairman of the Board and with the economic adviser of the Governor's Conference. They were greatly impressed by the possible mineral developments of Tanganyika, and in Uganda discussed the work of the Colonial Insecticide Research Unit and saw the field experiments in mosquito and tsetse control. In their report to the Council, they urged the establishment of a specific Colonial insecticide committee to coordinate research effort in the Colonial field and to bring to the notice of workers the latest information and advice. A list of publications and of patent applications is appended to the report.

\section{Colonial Social Science Research Council}

The third annual report of the Colonial Social Science Research Council, pointing out that progress in this field continues to be sporadic and unequal, emphasizes that the chief difficulty remains, that of finding the right man for a project. There has been little alleviation of the shortage of trained personnel, and more adequate provision is required for postgraduate training in the special techniques and skills and in the special background knowledge without which the social science graduate is not equipped for field work among the simpler and less-developed peoples. The Council has given much consideration to such training and records further progress in the preparation of programmes of research needs and priorities. Some twenty projects have been listed for priority in West Africa, and of projects mentioned in earlier reports Miss Phyllis Kaberry's study of the economic and cultural status of women in the British Cameroons, Dr. K. Little's ethnographical study of the Mende in Sierra Leone, Mrs. Meyeronitz's study of the role of gold in the art and culture of the Gold Coast, Mrs. Matson's study of the legal aspects of land tenure in the Gold Coast and Mrs. Ingram's documentary survey of social and economic conditions in the Aden Protectorate have been completed or almost completed, as is Dr. Geoffrey Tooth's study of mental illness and juvenile delinquency in West 
Africa so far as it relates to juvenile delinquency in the Gold Coast. New projects launched during the year include a sociological study of the peasant community in Jamaica, an investigation of secondary school science teaching in West Africa and a study of the relations between the extent of education and the after-school occupational life of girls and women in the Gold Coast. A project for a study of the efficiency of labour among the six thousand African employees of the Kenya-Uganda Railway stationed in Nairobi to be undertaken by a team of research workers under Dr. C. H. Northcott was also approved. The project has been planned in conjunction with the Human Nutrition Research Unit, on the recommendation of which there has also been launched a scheme for a survey of nutritional problems in all their aspects in the Gambia.

\section{Colonial Medical Research Committee}

The second annual report of the Colonial Medical Research Committee, in addition to reviewing research work completed or in progress, refers to the establish. ment of sub-committees to deal with nutrition problems, research on helminthiasis, and personnel as well as an East African Medical Survey Sub-Com. mittee, which has already prepared preliminary plans for a medical and sanitary survey as a first stage in a long-term policy of development to establish preventive medicine in East African territories. This was one of the main recommendations of the late Prof. McSwiney as a result of his visit to East Africa in 1946, and his other main recommendation for the establishment of a bureau of health in East Africa is being considered by the Committee in consultation with the East African Governor's Conference. The Colonial Medical Research Service has not yet been brought into being; although the results of most of the field trials of 'Paludrine' arranged in different Colonies are not yet available, the Malaria SubCommittee considering the relative prophylactic use of 'Paludrine' and quinine has expressed the opinion that 'Paludrine' is a superior drug to quinine for suppressive or prophylactic purposes ; in much higher weekly doses than $300 \mathrm{mgm}$. it has given no toxic manifestations, the latitude between effective and toxic dosage, for therapeutic purposes, being much greater than with quinine. It would be quite safe to sell 'Paludrine' in post offices and similar Government offices in the same way as quinine is now sold.

A research team has been dispatched to British Borneo under a three years scheme to study the transmission of malaria in that Colony, and a Nutrition Field Research Station is being established at Farjara near Bathurst in the Gambia. Following on studies of the microbiology of Kaffir beer and its nutritional value, the effect on the nutritional value for man of maize products obtained by various treatments is being investigated, and the physical and chemical changes in rice during soaking and steaming are being examined with the view of providing a satisfactory basis for parboiling rice. Another link in the co-ordination of Colonial nutrition work is provided by the formation of a Department of Nutrition in the London School of Hygiene and Tropical Medicine and the creation of a chair in nutrition in the University of London, to which the Director of the Human Nutrition Research Unit has been appointed. Research has been carried out on schistosomiasis in the United Kingdom at the London and Liverpool Schools of Tropical Medicine, while work on filariasis has been directed mainly to a search for a chemotherapeutic remedy. Arrangements have been made for work on scrub typhus to be continued at Kuala Lumpur.

\section{Committee for Colonial Agricultural, Animal Health and Forestry Research}

The second annual report of the Committee for Colonial Agricultural, Animal Health and Forestry Research refers to the attention given to the terms of service for the Colonial research worker, and a sub-committee under the chairmanship of Sir Edward Salisbury prepared a memorandum on terms of service considered suitable for a Colonial research service for agriculture, animal health and forestry. 'The sub-committee was primarily concerned to recommend terms that would attract and retain voluntarily in Colonial research a fair proportion of the available research workers in the sciences related to agriculture, and also that there should be no barrier to the free movement of research workers between research institutions in the Colonies and in the United Kingdom and the Dominions. The policy sub-committee was preparing a report on research needs of the Colonies and the organisation of research in Colonial regions. Some progress in the regional organisation of research in East Africa has been made as a result of the visit of Sir Frank Engledow, Prof. J. W. Munro and Sir Harold Tempany in February and March 1946, and the recommendations of a Conference at Nairobi for the replacement of the existing East African Agricultural Research Institute by an East African Agricultural Research Organisation on a more suitable site than Amani, and for the expansion of the East African Veterinary Research Institute at Kabete, Kenya, have now been accepted by the Secretary of State. Attention has also been given to the regional organisation of research in the West Indies, and schemes for research on soils, bananas and cocoa have been recommended by the Committee for assistance under the Colonial Development and Welfare Act.

The Cocoa Research Sub-Committee kept under close review the progress of the West African Cacao Research Institute [see p. 117] and examined in de. tail the West Indian regional cocoa research scheme as well as considering the control of cocoa virus diseases in Trinidad. A Soils Sub-Committee appointed during the year with Dr. W. G. Ogg as chairman dealt chiefly with Colonial soil classification and nomenclature, West Indian regional soils research and fertilizer experiments. The Stored Products Research SubCommittee has agreed with the Infestation Division of the Ministry of Food that infestation conditions in the West African territories should first receive attention, and has recommended a survey of these territories, to include the infestation problems of cocoa, ground-nuts, palm kernels and centrally stored foodstuffs for local consumption. Mr. G. S. Cottrell was appointed leader of the survey team in May 1946. A small working party has been appointed under the chairmanship of Prof. J. W. Munro to prepare a memorandum on the control of infestation for the guidance of Colonial governments, while other subjects engaging the attention of this SubCommittee have been the provision of entomologists and chemists for infestation control work and the use of the new synthetic insecticides in direct contact with stored foodstuffs. 